\title{
Urban development and emerging relations of informal property and land-based authority in Accra
}

\author{
Paul Stacey
}

\section{Introduction}

In September 2013, a celebration in the sprawling informal settlement of Old Fadama in Accra centred on the opening of a community-driven bakery and an adjoining local NGO offering legal advice to residents. Among the notables present who supported the projects were the Vice Consul of the Australian High Commission to Ghana, which partly financed the buildings, and representatives from the UNDP and Amnesty International. Although all constructions in Old Fadama are illegal, the centrepiece of the occasion was the unveiling of a plaque by a justice of the Ghana High Court. In January 2016 at another site in Old Fadama, a few hundred metres away, a five-storey hotel was close to completion. It towers over the surrounding ramshackle single-storey wooden shelters, eateries and kiosks. Neighbours explained that the immediate city authority, the Accra Metropolitan Authority (AMA), was strongly against the hotel but was powerless to stop its construction. People talked of a politically influential man who was behind the project, but nobody seemed willing to share knowledge of who he was. Other onlookers welcomed the hotel for bringing in business and raising the standard of the settlement with affordable and secure dormitory accommodation for market labourers. In Old Fadama, there is a bewildering variety of local, national and global actors that provide social, political and economic support in different ways for all kinds of land-based developments. Reflecting the diversity of resources that are invested, some buildings are more prominent and more 'developed' than others, but all contribute to shaping the urban landscape and illustrate the informalization of property relations in a central district of Accra, where all building is outside the control of statutory institutions. Therefore, the expansion of Old Fadama raises thought-provoking questions about how urban land is actually accessed and controlled, and what the different land-based developments mean for statutory rights to land.

Africa's population is expected to double to some 1.3 billion people by 2050 , and the number of people living in slums is also expected to increase sharply because most will seek out the cheapest urban accommodation as well as the casual labour opportunities that such areas offer (Cohen 2006: 64; UN-Habitat 2011: 1). ${ }^{1}$ A related issue is that tens of thousands of rural-urban migrants in Africa will establish livelihoods in informal settlements on land that formally

\footnotetext{
Paul Stacey is a post-doctoral researcher at the Section for Global Development, Department of Food and Resource Economics, University of Copenhagen. Email: pas@ifro.ku.dk

${ }^{1}$ Potts disputes the broad understanding that urban populations in Africa are generally increasing (Potts 2012).
} 
belongs to others. ${ }^{2}$ However, the growth of informal settlements in sub-Saharan Africa has many drivers and is not immediately attributable to rural-urban migration alone. One dominant factor is the long-term deficit of comprehensive urban planning experienced in many African cities. This is often attributed to the retreat of the state from the public sphere and the era of economic structural adjustment policies from the mid-1980s (Peck and Tickell 2002). Other related factors include a sharp reduction in the size of African public sectors, a drive to privatize public utilities, urban investor preference for high-end housing and apartment blocks, and market-based policy logics that demonize social housing as antithetical to economic growth. These forces have created socio-economic and political fragmentation in cities and have widened the gap between the endeavours and actions of ordinary people to access land and build houses, on the one hand, and government plans and investor blueprints for urban landscapes that favour private properties that are unaffordable to most on the other. Generally, market-based logics have also lessened any political will to make long-term plans for the equitable use and distribution of urban public space, and mean that the urban poor and vulnerable are often not taken into account in urban planning (Carmody and Owusu 2016; Watson 2009). At the same time, there are numerous sprawling informal settlements and slums in sub-Saharan African cities that governments are begrudgingly forced to accept, because neither eviction nor relocation is politically, socially or economically viable. Tacit acceptance can stem from the urban poor's increased access to social media, which can hold parliamentarians to account, and there are increasing numbers of NGOs and civil society organizations that take up issues pertaining to urban marginalization. These frame their objectives around government pledges and pro-poor statements made at global events such as the World Urban Forums in Barcelona (in 2004) and in Vancouver (2006), and around global developmental agendas such as the millennium development goals and more recently the sustainable developmental goals, to which many African governments have themselves made commitments. Still, despite various governments of Ghana being signatories to different covenants, the issue of whether Old Fadama residents benefit from occupational rights to the land is unclear. The multiple pressures on land and housing can mean that governments face a near impossible task of balancing between market-driven interests in land, pro-poor global agendas for better housing, the desire to slow down rural-urban migration, the need to discourage illegal settlement, and the wish to make cities attractive destinations for foreign and commercial investors. One outcome is that African governments may be pressured to reject eviction as a possible policy option. Another is that political rhetoric may shift to 'relocation' or the 'upgrading' of illegal sites of residence. It is in this context of divergent government objectives and urban expansion that the informal settlement of Old Fadama has taken root in Accra.

\section{Empirical, conceptual and theoretical perspectives}

This article explores the emerging property relations linked to land-based urban developments in Old Fadama and answers calls to reconsider the conceptual

\footnotetext{
${ }^{2}$ There are numerous definitions of informal settlements. The UN definition is that they are housing areas that occupants 'have no legal claim to, or occupy illegally' (UN 1997).
} 
and theoretical foundations of many urban studies in developing countries. Broadly, Eurocentric thinking based in Weberian, ideal-type trajectories means that land-based development is often assumed to be under the control of statutory institutions, with the apparent failures of urban planning suggesting that African states are weak. But this is based on a teleological understanding of political development that sees Africa juxtaposed against the West and power projected from a central entity with geographically circumscribed power (see, for example, Evans et al. 1985; Herbst 2000). Such state-centrist understandings also allude to a belief that formal and informal institutions are mutually exclusive, with state institutions assigned positive traits of rationality and formality, and society framed as an ineffective and disorganized counterpart (for example, Chazan 1983; De Soto 2000). Informal settlements are consequently reduced to futile sites, although their structural conditioning is easily overlooked. In line with dominant understandings, the control of landed property is often apportioned to statutory institutions (Shachar and Hirschl 2007). Furthermore, property is commonly understood in terms of absolute or private ownership or as a physical object. But outright ownership rarely, if ever, exists because possession is conditional and is related to the actions of others who exercise their rights and claims (Rose 1998).

In contrast to Eurocentric views, there is recognition that governance is not produced by the state or government alone, but through competition, contest and negotiation between heterogeneous statutory and non-statutory institutions with agency assigned to actors at the grass-roots level (see Fourchard 2011; Locatelli and Nugent 2009; Stacey and Lund 2016). A key difference is that cities in the global South are understood in their own right and re-imagined, re-theorized and re-conceptualized with a focus on 'what is actually going on' at the street level, as opposed to 'what should be' or 'what is missing' (for example, Chernoff 2003; De Boeck and Plissart 2004; Grant 2009; Myers 2011; SaglioYatzimirsky 2013; Simone and Abouhani 2005). These understandings provide the point of departure for this article, which shows that different conjunctures of statutory and non-statutory interests shape the making and unmaking of urban relations of informal property and land-based authority. This article consequently approaches property as a set of changing relationships that endeavour to control and legitimate land use and which may or may not involve statutory institutions directly. To gain insights into the making and legitimation of informal property and land-based authority, I examine different cases of the transfer of and building on land in Old Fadama, and the process from claim making to the substantiation and recognition of land use by others. ${ }^{3}$ The cases show that property relations concerning land are produced by a host of different, loosely connected actors and add to understandings of what we consider 'ordinary' cities (Robinson 2006) and 'globalized' cities (Grant 2006). The evidence shows how spatial differentiation develops; in urban contexts in the global South, this is often explained in terms of Marx-inspired processes of urban accumulation by

\footnotetext{
${ }^{3}$ Legitimacy is defined by Uphoff (1989: 295) as 'a conviction on the part of persons subject to authority that it is right and proper and that they have some obligation to obey, regardless of the basis on which this belief rests'. Public authority is defined as the ability to exert a non-covert, impersonal power over a demarcated space, with popular legitimacy that does not rely solely on coercive force (Lund 2006).
} 
dispossession. Here, excess capital turns the over-availability of cheap labour into profit and results in class-based land struggles (Bailey 2014-15; Gillespie 2016; Harvey 2003). In contrast, this article shows evidence of different 'class' categories working together to legitimate control over land in order to make development possible. Also, there is evidence of fragmentation within Old Fadama itself, so the ordinary is the forming of a patchwork of complementary and competing stakeholders with very different interests but which together make building possible. Each land-based development is shown to rest on its own logic of support. It is beholden to its own set of participants, and these differ from those of neighbouring developments in terms of a range of resources that include spatial reach, knowhow, developmental ambition and justification for building. The actors involved in the different developments are not explicitly creating local relations of property and land-based authority, but they establish context-specific understandings about what their rights to land are based on, and they influence the ability of statutory institutions to exercise their will and enforce the rights they recognize. Consequently, land-related developments in Old Fadama are shown to produce heterogeneous forms of informal property and authority that are more fragmented and complex than those alluded to by explanations based on either theories of accumulation by dispossession or socio-economic class categories.

In 2002, the AMA served an eviction order on Old Fadama and shortly afterwards residents failed in their demonstrations and petitions to the High Court to overturn the ruling. The eviction order still stands today and limits the level of formal support available from branches of government. The illegality of Old Fadama means that there is a physical absence of statutory institutions and there is no formal recognition given to any building activities. But in the space between a lack of formal recognition and the local demand for land, a host of alternative arrangements around property have emerged and developed. This conjuncture makes it useful to distinguish between people's ability to benefit from land that is based in socio-political and cultural relations, and specific rights to property that are backed up by state laws or customs (Ribot and Peluso 2003: 155). The cases in this article exemplify the former and demonstrate how the making of 'alternative' local property relations is shaped by the inaction and inability of statutory institutions to exercise their will (Sikor and Lund 2009). As stakeholders rally support wherever they can find it, the process of gaining control over land in Old Fadama is haphazard. However, it is not inherently conflict-ridden: it is characterized more by consensus seeking and compliance than by coercion and might. This finding runs counter to several other dominant conceptualizations of informal settlements: as disorganized and deprived of agency (for example, Kaplan 1994; Davis 2006); as sites prone to violence at the conflation of urban poverty, insecurity around land, lawlessness and social tensions (for example, Barry et al. 2007; Beall et al. 2011; Lombard and Rakodi 2016; De Soto 2000; De Souza 2001); as arenas of socio-political or economic homogeneity; or as areas occupied by those marginalized from globalization processes (for example, Mohanty 2006; Shabane et al. 2011). Although many of the negative and problematic features listed above are certainly observable in Old Fadama, they are not defining traits of land transfers in the area because they do not provide satisfactory explanations for the diversity of land-based developments taking place. But at the same time, Old Fadama, located about 3 kilometres from Accra's central business district, is known locally as 'Sodom and Gomorrah' 
by proponents of its destruction, as well as by some residents who take pride in or joke about its notoriety and professed high levels of lawlessness. ${ }^{4}$ Altogether, the multiplicity of land relations in Old Fadama confirms that, despite the 'widening, deepening, intensification' of local and global connections found in African urban spaces, the impact on local development remains considerably uneven (Fourchard 2011: 231). Moreover, narratives of African informal settlements as chaotic are challenged by studies of inventiveness and ingenuity, including the local mimicking of ostensibly official building regulations and the use of standard and accepted materials to gain broader legitimacy. The copying of physical versions of the "original' city produces notions of urban homogeneity and boundary-less spaces between legal and illegal settlements, and can improve a sense of belonging and reduce uncertainty experienced by residents (Hansen and Verkaaik 2009; Lombard 2013; Nielsen 2011). In Old Fadama itself, studies of land dynamics have focused on processes of exclusion, class-based dispossession and state institutions rallying against an 'informal proletariat' (Gillespie 2016). Access to land has also been explained as dependent on individuals' positioning in patronage networks and residents' proximity to political entrepreneurs (Paller 2015). And negative discourses of 'informality' and 'squatters' in Old Fadama adopted by politicians and the media have been used to explain how questions of development become intractable as the site is isolated from the rest of 'normal' Ghanaian society and is framed as an undesirable aberration (Afenah 2012; Obeng-Odoom 2011).

The article is based on qualitative data collected over nine visits to Old Fadama from July 2014 to July 2016, totalling about six months. This included over twenty semi-structured interviews with a range of stakeholders, including politicians, planners, community leaders, elders, shop owners, residents, local NGOs and local developers in and around Old Fadama. In addition, ethnographic observation and focus group interviews with mixed groups of residents were undertaken. The next section provides a broad description of land tenure systems in Ghana and serves to help understand land dynamics in Old Fadama. Next is a brief history of settlement and land disputes in the area, followed by the four cases of land-related development.

\section{Outline of land tenure in Ghana}

In Ghana, customary authorities hold about 80 per cent of land and the remaining 20 per cent is state owned, but the land administration system comprises a mosaic of some twenty-three different informal and formal institutions (Campion and Acheampong 2014; Spichiger and Stacey 2014). In Ghana, as well as elsewhere in sub-Saharan Africa, there is a complex legal pluralist framework around land issues, giving rise to overlapping claims, contentions, disputes, land-related litigation, uncertainty and insecurity of tenure (Ayee et al. 2011: 7-8;

\footnotetext{
${ }^{4}$ The name is based on the biblical story of God's wrath and destruction with fire and brimstone. Agbogbloshie was described as 'the highest toxic threat to human life' on the planet in a 2013 study of 3,000 sites in forty-nine countries by the Blacksmith Institute/Green Cross; see Siva Parameswaran, 'Toxic waste "major global threat", BBC News, 2 November 2013 <http:// www.bbc.com/news/science-environment-24994209>, accessed 20 October 2017.
} 
Government of Ghana 2011: 2). Legally held rights can therefore experience local rejection, while claims to land that appear to contradict the law may be locally legitimate (Berry 2002; Stacey 2015). According to Ghana's 1992 Constitution, it is chiefs, traditional authorities or heads of families who are the custodians of the 80 per cent and who oversee transfers through a fiduciary obligation. In the case of chiefs, the relevant customary institution is called the skin in the north of the country and the stool in the south. The skin and stool symbolize the authority of the traditional institution, the territorial extent of a given chiefdom, and the chief's veneration of the skin or stool ancestors. Accordingly, the skin and stool symbolize the inseparability of group identity, land and authority (BentsiEnchill 1964: 30).

However, it is widely accepted that the legal pluralist administration, management and distribution of land are malfunctioning in Ghana. Exclusion and marginalization from land are common and often legitimated with reference to socio-political criteria such as age, gender, ethnicity, religion or political affiliation. Meanwhile, since the colonial period, agency vested in tradition and chieftaincy to manage land affairs has created numerous, seemingly insoluble disputes centred on chiefly appointments and local questions of autochthony. Thus, land issues are closely connected to questions of citizenship status and rights, and 'native' members of a stool or skin community are ranked higher than designated 'migrant' groups (Nugent 2010; Stacey 2015). Furthermore, contests over land are seldom only about the land, but concern the power relations that endeavour to define and substantiate the rights of different categories of people (Lund 2016). These broad features are now situated within the context of land issues in Old Fadama.

\section{Land claims and the role of the state}

Settlement in Old Fadama can be traced back to Hausa and other migrants who established peri-urban villages around Accra from the late nineteenth century (Acquah 1958). ${ }^{5}$ Since then, there have been three political and historical dimensions of land-related contests over the area (Grant 2006). The first was a dispute that commenced in the colonial period between the traditional claims of the $\mathrm{Ga}$ ethnic group, for whom the area is sacred, and plans for urban infrastructure development promoted by the colonial administration. The second followed the same pattern of a dispute between colonial and customary institutions; this continued into the period of Ghana's independence, when, in 1961, Kwame Nkrumah's government acquired control over the area for manufacturing and light industrial purposes, once again sidelining the traditional claims of the Ga. Despite the plans for development, however, Old Fadama was left largely untouched, and its relative lack of occupation and its centrality meant it became an attractive site of settlement for rural-urban migrants. Rural-urban migration and prolonged settlement on the site have characterized the third dimension of contest. Many street traders and hawkers made the area their

\footnotetext{
${ }^{5}$ From Hausa: fàdáma means a marshy ground for agriculture.
} 
home following decongestion exercises undertaken by city authorities elsewhere in Accra in 1991 in connection with a Non-Aligned Movement conference. And later, in 1993, the government gave temporary permission for a yam market to be established in Old Fadama, which made the area especially attractive to Konkomba agricultural traders from the northern regions of Ghana. Konkomba kinsmen were also drawn to Old Fadama in 1994, together with many other ethnic groups fleeing ethnic violence in the northern region and north-east of Ghana (Gillespie 2013: 160-3; Jönsson 2007). Old Fadama has therefore become an option for urbanites who have fallen on hard times elsewhere in the city and is a well-established first stop for all kinds of hopeful rural-urban migrants. More generally, the growth of Old Fadama has contributed to Ghana's urban population more than tripling between 1984 and 2014 (World Bank 2014).

The overall position of the Ga traditional state is that successive governments since 1961 have breached their side of the expropriation agreement because the promised local development has not materialized and the natural ecology of the Korle Lagoon has been destroyed. ${ }^{6}$ Today, Ga traditional and spiritual figureheads often voice strong opposition to Old Fadama as an affront to their authority and argue that the land should be returned with compensation for restoration. To put it simply, there are three groups of land-related stakeholders: 'government' (statutory institutions and actors), 'natives' (Ga traditional authorities), and the 'squatters' (residents). None of the groups has full control over land issues and all have pursued contrasting agendas, hence there is no dominant set of rules or any coherent group of actors that compellingly controls the land. Driven by the contradictory positions of statutory institutions and the circumvention of the law and custom by settlers, Old Fadama has now been a significant site of settlement and building for at least forty years. Different government departments may turn a blind eye to the site, begrudgingly accept illegal constructions, voice public opposition, or target specific areas for bulldozing. Thus, the continued act of settlement exemplifies the active undermining of statutory authorities and city government as well as an inability or unwillingness to control the practical consequences of the judicial ruling that settlement is illegal. As shown in the opening vignette, there are apparent contradictions, with a High Court judge openly validating the new community-based project on the site, and with support being given to the opening of a local NGO that offers legal advice to 'squatters'. This event also reveals the central role that the institutions of foreign nation states in this case the Australian High Commission to Ghana - can play in local initiatives that defy the will of city authorities and the letter of the law to halt settlement and construction.

The size of Old Fadama is an advantage because it is more difficult for city authorities to tackle than smaller sites of informal settlement, which are sometimes totally demolished. In 2014, for example, around 5,000 residents of the informal settlement of Mensah Guinea were given three days' notice to leave before bulldozers razed the area. ${ }^{7}$ And in June 2015 several thousand Old Fadama

\footnotetext{
${ }^{6}$ Interview with Ga priest, 9 July 2014.

${ }^{7}$ Nathaniel Yankson, 'AMA pulls down illegal structures at Mensah Guinea in Accra', Myjoyonline.com, 5 September 2014 <http://www.myjoyonline.com/news/2014/september-5th/ ama-pulls-down-illegal-structures-at-mensah-guinea-in-accra.php>, accessed 19 October 2017.
} 
residents living in perimeter areas lost their homes to government bulldozers although the greater part of Old Fadama was left intact. The AMA objective here was to reduce congestion and to create a buffer zone between Old Fadama and the adjacent Odaw River to reduce the risk of flooding. This clearance operation followed a calamitous combination of fire and flooding at a petrol station adjacent to another informal settlement at Kwame Nkrumah Circle in Accra, which had claimed over 150 lives earlier in the same month. Thus, demolition is often justified with reference to public health and safety rather than issues of illegal settlement and rights to land. ${ }^{8}$ Still, recent episodes show that the AMA breaches the spirit of various global pledges towards slum dwellers in order to claw back control over urban space, but is unable to control or halt everyday, informal building activities and encroachment on land. ${ }^{9}$ Besides the intermittent clearance operations, city authorities have endeavoured to preserve a presence in Old Fadama by registering and taxing the countless small businesses that proliferate there. This suggests that, parallel to the process of squatting, a policy of normalization is pursued that intends to make society legible and introduce 'a common standard necessary for a synoptic view' of urban development (Scott 1998: 2).

In the Accra municipality, Old Fadama is by far the largest out of a total of seventy-eight registered slum sites. Thirty-four of these are categorized as having either 'insecure' or 'none' tenability, with Old Fadama registered as 'insecure'. ${ }^{10}$ An NGO count in 2009 numbered the population of Old Fadama at just over 79,000 (Farouk and Owusu 2012). The settlement has a very young population, with nearly 38 per cent, or 30,000, under the age of eighteen. Of these, the 2009 count estimated that about 65 per cent do not attend any form of schooling (Housing the Masses 2010: 9). Almost all of the population are Ghanaians and nearly three-quarters originate in the country's northern regions; some twothirds are Muslim. Old Fadama comprises a 31-hectare site, roughly triangular in shape, hemmed in by a major truck road to the north and the Odaw River and Korle Lagoon waterways on the other two sides. The site has managed to expand spatially as settlers have filled in the waterways, river banks and floodplains with sawdust and city waste, which provide a spongy base to build upon. According to city authorities, the constant process of encroachment, landfilling and uncontrolled construction has greatly increased the risk of flooding in both Old Fadama and central areas of Accra that are upstream because the flow of water, waste and effluent from the city out into the Gulf of Guinea has been obstructed.

Both Old Fadama and neighbouring Agbogbloshie experience substantial land, water and air pollution, which poses risks not only to the immediate vicinity but to large parts of the rest of Accra as well (Songsore et al. 2014). The main causes of pollution include severe traffic congestion, widespread open sewers and untreated

\footnotetext{
${ }^{8}$ Billie Adwoa McTernan, 'Accra slum dwellers suspect cholera demolitions are a pretext for profit', Guardian, 20 October $2014<$ http://www.theguardian.com/global-development/2014/oct/20/accracholera-ghana-mensah-guinea-slums-demolished-commercial-profit>, accessed 20 October 2017.

${ }^{9}$ For example, the Millennium Development Goal 2015, Target 7D, is to 'achieve, by 2020, a significant improvement in the lives of at least 100 million slum dwellers'.

${ }^{10}$ Status as a 'slum' is based on access to sanitation and water, population density, housing quality and security of tenure (UN-Habitat 2011). At over 2,500 people per hectare, the population density of Old Fadama is about ten times that of Manhattan (Farouk and Owusu 2012: 55).
} 
landfill, unregulated light industries, oil dumping by countless garages and workshops, and the burning of electronic waste, plastic and rubber outer coatings of electric cables. In recent years, the adjacent site of Agbogbloshie has attracted global media attention as an expansive toxic dumping ground for electronic waste from the USA and Western Europe. Resource flows are based mainly around informal patronage networks, negotiated between line ministries and non-governmental intermediaries, and follow election cycles as political interest in the site waxes and wanes and largesse translates to party political support.

Although the substantive issue of illegality has not been settled, since 2006 the internationally affiliated NGO People's Dialogue on Human Settlements has experienced relative success in bringing city authorities and resident groups together and has helped form the community-based Old Fadama Development Association (OFADA). This is a group comprising ethnic, community and traditional leaders that endeavours to improve the provision of basic public services and regulate building. The absence of statutory institutions and public service provision in the area, however, is very obvious. There is a lack of planned infrastructure and little regulation of public spaces, and the site is without roads, traffic lights, pavements, health clinics, post offices, state schools, public buildings, street names or house numbers (Stacey and Lund 2016).

\section{Examples of development in Old Fadama}

I now present four different cases of land-based development that exemplify the making of context-specific informal property relations that validate and authorize land rights. The first case concerns the building of a school, the second a hotel, the third a public bridge, and the fourth a pharmacy. Common to these cases is the way in which they are unfettered by formal state law, while land use extends beyond individual shelter and housing to comprise relatively large constructions enjoyed and legitimated by many members of the community.

\section{School building}

Due to the young population there is a high demand for childcare and education, but there are no state nurseries or schools in Old Fadama, nor are there any secondary schools in the larger constituency of Odododiodoo, of which Old Fadama is an electoral ward. This demand has driven the growth of several private and NGO-financed nurseries and junior schools in Old Fadama. One such is Paulina's Queensland School, which started as a small nursery in 2007 and now has some 400 registered students with about 280 daily attendances. Pupils are taught by four formally trained teachers out of a total of twelve, with intermittent volunteer teachers. ${ }^{11}$ The school started as a hotchpotch of wooden shacks but today has the look and feel of an under-resourced government school, with cramped classrooms and old-fashioned wooden desks, chairs and blackboards. The pupils wear a uniform of brown and yellow that is the same as the one for government schools, and there is a staff office, school dinners, and a traditional

\footnotetext{
${ }^{11}$ Interview with headmaster, 23 August 2014.
} 
hierarchical and pedagogical approach to teaching, with classes based on age. The school is squeezed into a three-storey building that itself is jammed between a mass of shacks and winding paths just wide enough for bicycles to pass through. Despite the problematic legal status of the settlement, however, the school enjoys a level of recognition by different state institutions. For example, it receives support from the Ghana Education Service (GES) in the form of registration of pupils, accreditation of the curriculum and the setting of exam standards, and the school is also registered as a private school with the Ministry of Education. As a registered business it also pays taxes to the AMA. However, it does not receive any economic support from state coffers and is solely reliant on enrolment fees, donations and voluntary work.

By 2013 the increase in pupils meant that a large extension to the school was necessary. To this end, the school contacted its neighbours and encouraged them to 'do the right thing for the benefit of the children' by either moving their wooden shacks closer together, which was relatively easy to do, or by selling plots to the school to free up space for the much needed annex. Leverage over neighbours was gained by highlighting the vital role that the school played in the community. ${ }^{12}$ At the same time, global support from a US-based evangelical NGO was obtained. This organization participated in negotiations with neighbours and provided the funds for the building materials and the purchase of plots for the extension. Their country representative explained their considerations:

We had to go in for it because we've seen in the past years that politics are at play. We keep on hearing the place [Old Fadama] will be demolished. The fee was large for that small piece of land [but] we promised to raise the money. The issue [was] that it's about the children wanting to have a classroom who cannot be going through all this. We know as an organization that anything can happen, but one thing was that it's a school! So if they [the city authorities] break everything, [they] probably might leave the school for us, so that was the idea. We don't even know who [the rightful owners are]. So the system is not right. [And] as soon as someone knows you are paying something, everybody wants something, so we dealt with the person who said the land belongs to him, and he gave an offer to sell the land [but] we knew it didn't belong to him! It belongs to either the nation, or the AMA, or the government, or the Ga. ${ }^{13}$

Thus, the process of obtaining land for the school took as a point of departure the actual interests, claims and social relations around the site, and involved a diverse group of actors. The involvement of different actors and the compromises made meant that the transfer of land and the new building became locally embedded. The school established rights to land through the cooperation and active involvement of neighbours, who in turn recognized and validated the use of the land.

\section{Hotel construction}

The following elaborates on the example in the introduction about the building of the hotel. It shows that local rights to land were created as both the AMA and customary authorities proved unable to control the development. There are three

\footnotetext{
${ }^{12}$ Ibid.

${ }^{13}$ Interview with country representative, 1 August 2014.
} 
representatives of Ga chiefs in Old Fadama who try to monitor and regulate building activities. They scout around to gain acknowledgement from builders (and, if possible, they collect payment) and they inform them about Ga customs that establish that the land being built on belongs to the Ga. But they are unable to keep track of all new constructions and do not have the power to enforce sanctions when their requests are ignored. The position of the Ga representatives in Old Fadama is further weakened by divisions between different Ga clans. While some Ga claim that collecting 'tribute' from builders helps sustain a traditional Ga presence in the community, others argue that 'fees' should not be collected from anyone because payments are interpreted as Ga accepting settlement on the land, when in fact the sacred site should be untouched and returned. There are also complaints from some Ga stakeholders that 'the wrong Ga people' are making money from land transactions, as there is little or no documentation used. ${ }^{14}$

However, the plot for the hotel was originally allocated 'a number of years ago' by a 'Ga chief' for someone to start up a chop bar (a stand selling skewered and grilled meat), but this was destroyed by fire in the early 2000s. The chop bar owner started to rebuild the stall with concrete blocks but after several years conceded that it was unaffordable and started to look for buyers. In 2014 the plot was sold for a 'substantial' price to a local businessman and the chop bar owner 'ran away' with the money. ${ }^{15}$ The Ga representatives explained that they were not involved in the transfer and only found out about it much later when they saw that construction of the hotel had commenced. Their position was that the chop bar owner had no right to sell and that the land - or at least a portion of the money from the sale - should have been handed to them. The bypassing of the Ga representatives led to their traditional superior wanting to halt the hotel construction because it was an affront to his authority as the customary landowner. He complained to the AMA and unsuccessfully demanded that they halt the construction or ensure that building standards were followed. ${ }^{16}$ Meanwhile, the issue of unregulated buildings and informal settlements in Accra had become the subject of increased popular and political attention because of the disastrous combination of fire and flood (described previously) that occurred in Accra in June 2015. While pressure on the hotel construction mounted, the stakeholders behind it gained the support of leading members of OFADA. Building continued and the AMA did not intervene because of a combination of politically influential investors, a fear of violence, and the challenges that demolition would bring because the hotel was located in a densely built area of Old Fadama. ${ }^{17}$ Eventually, the AMA pressured OFADA to communicate an outright ban on all new buildings in Old Fadama. The hotel was exempted from the ban because it was already near completion and by this time it was clear to most people that it would not - or could not - be halted. Still, the ban boosted OFADA's local image as a regulatory authority for building and it signalled to residents that the

\footnotetext{
${ }^{14}$ Interview with Ga priest, 9 July 2014.

${ }^{15}$ Interview with residents, 3 June 2016. Despite persistent attempts, it was not possible to talk to either the investor behind the hotel or the previous chop bar occupier.

${ }^{16}$ Interview with Ga representative, 3 June 2016.

${ }^{17}$ Interviews with residents, 3-4 June 2016.
} 
AMA was powerless to do much itself. A leading OFADA member rationalized afterwards about the benefits the hotel would bring and expressed his support for the hotel that everyone seemed unable or unwilling to stop:

I see that as a leader of the community, I think my people also deserve that kind of thing [the hotel] to be given to them. So I will not sack [force] the man not to invest. [So] that's where we agreed, that when you are going to do it, you make sure that you do it, not because you want money, but because you are coming to save the people of Old Fadama. ${ }^{18}$

In this case, hidden economic and political interests have managed to wrest control over a site and gain the right to land in open defiance of statutory authorities and the customary landowners. The construction of the hotel has also gained local backing because it runs counter to the position of government and because it exemplifies local economic and development ambitions to make Old Fadama resemble any other part of the city. Thus, the project is not socially embedded like the school but it is similarly justified locally as having a social value, and it has produced non-statutory, informal property relations that challenge the position of statutory institutions. This is evident in the way in which the AMA has endeavoured unsuccessfully to gain influence over the construction of the hotel. The AMA has not only effectively been excluded, but it has had to 'outsource' regulation to a non-statutory organization in the form of the OFADA, which has also proved either unable or unwilling to follow up on the AMA's demands.

\section{Bridge building}

At another site in Old Fadama, a steady stream of people traverse three rickety wooden bridges that are each about 50 metres long and that stretch over a garbage-strewn gully that borders the site. At the end of one of the bridges, two youths sit listening to the radio under a parasol, on makeshift chairs and with a plastic bucket inviting passers-by to throw coins. All who cross the bridges apart from schoolchildren, who are exempt - willingly pay a toll of five or ten pesewas, depending on the length of time spent 'on the other side'. The bridges join the settlement to an extensive dumping ground for city waste supplied regularly by trucks. High up on the mounds of garbage are 'pickers' who come across from the settlement and glean various leavings for future sale. These are tied into large bagged headloads and carried back across the bridges into the city. The bridges serve as convenient shortcuts to homesteads, working places, schools, transport hubs and markets. A single headload incurs no extra cost, while motorbikes, barrows and animals cost more. ${ }^{19}$ At the end of another bridge sits Adam, collecting coins; he built the bridge with his brother about fifteen years ago. $\mathrm{He}$ explains:

After I got here I saw an opportunity to build a bridge over the gully. There was nowhere to cross and it was getting flooded. I thought we should do something here because there are schoolchildren everywhere on the main roads and at any time a car can knock them

\footnotetext{
${ }^{18}$ Interview with OFADA member, 3 December 2015.

${ }^{19}$ This vignette also appears in Stacey and Lund (2016).
} 
down. That's why we don't like to allow motorbikes on the bridge, because it is for the children. I paid some money to a Dagomba chief in Old Fadama who allowed me to build. Besides, when anyone uses the main road at night-time they were easily getting robbed and attacked and with no street lights it was always dark. But with our own bridge we could ensure there was always someone there. It took us over six months to build this thing. We gathered scrap wood and bound it together. The first time we made it stretch over to the other side we thought the worst was over. But the water came and took it all away and we had to start again. We learned from that - that anytime it rains we can lose the bridge. So we got hold of some big iron girders and welded them together that extended over both banks. That was what we wanted! Then we built the wood around them. So for the past many years I am here for the schoolchildren. I cannot go and leave them. My mind is on them so I can't leave them. I'm waiting for the day the AMA come and say this place is no more, then I can leave and go home!

Here, we see how a local entrepreneurial activity has become a vital part of local infrastructure and in so doing has gained local acceptance and recognition and has become socially embedded. The bridge is not managed or planned by government but has earned the tacit acceptance of city authorities - it is difficult for them to intervene because of the important role the bridge plays. Adam's right to the land was first established through the Dagomba community, whose chief initially allocated the site and gave him permission to build. But in an everyday capacity the right to the land is substantiated by the scores of very different people who use the bridge and willingly pay the toll, and through the non-interference of government.

\section{A pharmacy business}

George was one of the many thousands of northerners who moved to Old Fadama in 1994 with the dual objective of escaping the ethnic fighting and pursuing an education in the capital. With relatives in Old Fadama and "nowhere else to go', he promptly left for the capital. George now has a well-kept pharmacy on one of the main alleys into Old Fadama that stands out from the surrounding rickety wooden shacks and impromptu stalls. The shop is made from concrete blocks and is more prestigious than most of the neighbouring premises. It has a tin roof, tinted glass and doors, and a raised tiled pavement area. Inside, a television on the wall provides background noise and distraction. The shop has ceiling fans and a tiled floor and is well stocked with all kinds of medicine on dusty shelves. George provides advice, collects money from customers, and hands out things for free to others. His primary motive for business is economic, but there is also a social obligation attached to being a pharmacist in the deprived community. Importantly, the social capital he accumulates from providing a vital service to the community is reciprocated by the community recognizing his right to the land. In the absence of formal documentation, he explains that it was a broad group of neighbours who initially acknowledged that the owner of the plot had the 'right' to sell it, and it was the same group of neighbours who recognized the 'right' of George to purchase the plot. He emphasizes that accessing the land was helped by the need for a pharmacy in the community. As such, George's right to the land is based on the social relations he has established with neighbours as well as the purpose, patronage and customer base of the business. He explained: 
I bought the land with no papers from a guy. I knew him but when word spread I wanted a place to buy, someone put me onto him. He immediately sold it and left the area. I paid everything, in cash, and in one go. The deal here, though, is like, if the community can see you respect yourself, then they will respect you. It worked for me because the guy knew I was credible, so when he sold the place to me I didn't face any problems. I just established my business. But if you're a rascal you will be dealt with like one!

Similar to the local services provided by the school and the bridge, we see here how the use of the land and patronage by the community provide local acknowledgement and acceptance. This is evident as George explains that it is important to be deemed benign by the community and that security is assured because the wider community acknowledges his social contribution, as well as the role the pharmacy plays as a provider of healthcare. This is similar to the social embeddedness of property relations based in the toll bridge: George's business success is reliant on the social recognition of the surrounding community. In this way, local service providers such as Adam and George move beyond their status as squatters (as government otherwise perceives them) and enjoy an elevated status as worthy subjects of a community that recognizes and substantiates their rights to the land because they contribute to local development.

\section{Conclusion}

Western paradigms based on state recognition of property rights cannot adequately explain the many forms taken by property relations in Old Fadama. Here, the development of land and relations of informal property are based on a wide range of loose, context-specific social, political and economic relations in which documentation plays no role. Local legitimation of land use and the acknowledgement of land rights are processes that are not substantiated once and for all, but are recognized and secured by diverse groups of people through mundane everyday practices, usage and patronage. Rights to land are thereby underpinned by loosely organized and separate community bodies that involve different statutory and non-statutory actors and institutions across local, national and global scales. The informal relations of property develop because of the social and political spaces that open up as a result of the physical absence of any powerful statutory institutions and because of local demand for land, services and infrastructure. Land-based developments reflect and produce power relations that define land use, control and ownership. Meanwhile, the absence of state support for badly needed infrastructure and the dearth of public services in Old Fadama provide local projects with a justification and a sense of urgency, and create understandings of belonging along the lines of 'If we don't do this nobody will' and 'It is important that we all support this'. Thus, land-based developments demonstrate acts of defiance by 'Old Fadama' against an unhelpful 'government', and contribute to the making of communities. Land-based developments may not have an obvious or explicit social function or value, but they often have a justification in social terms, which demonstrates the significance that social relations play in accessing land. Overall, the diversity of land-based developments that enjoy the tacit acceptance of statutory institutions in Old Fadama is suggestive of an important structural challenge of urban development more generally in Africa. 
There is a widening gap between the way in which ordinary people validate land rights and the logic of formal state law that endeavours to do the same.

\section{Acknowledgements}

This research was kindly funded by the Danish Council for Independent Research / Social Sciences (FSE).

\section{References}

Acquah, L. (1958) 'Accra survey: a social survey of the capital of Ghana, formerly called the Gold Coast, undertaken for the West African Institute of Social and Economic Research, 1953-1956'. Accra: Ghana Universities Press.

Afenah, A. (2012) 'Engineering a millennium city in Accra, Ghana: the Old Fadama intractable issue', Urban Forum 23: 527-40.

Ayee, J. R., A. K. D. Frempong, R. Asante and K. Boafo-Arthur (2011) 'Local power struggles, conflicts and conflict resolution: the causes, dynamics and policy implications of land-related conflicts in the greater Accra and eastern regions of Ghana'. Research Report 3. Dakar: CODESRIA.

Bailey, G. (2014-15) 'Accumulation by dispossession: a critical assessment', International Socialist Review 95.

Barry, M. B., D. Dewar, J. F. Whittal and I. F. Muzondo (2007) 'Land conflicts in informal settlement: Wallacedene in Cape Town, South Africa', Urban Forum 18: 171-89.

Beall, J., T. Goodfellow and D. Rodgers (2011) 'Cities, conflicts and state fragility'. Crisis States Research Centre Working Paper 85. London: London School of Economics and Political Science <http://www.lse.ac.uk/internationaldevelopment/Assets/Documents/PDFs/csrc-working-papers-phase-two/wp85.2cities-conflict-state-fragility.pdf>, accessed 1 November 2017.

Bentsi-Enchill, K. (1964) Ghana Land Law: an exposition, analysis and critique. London: Sweet and Maxwell.

Berry, S. (2002) 'Debating the land question in Africa', Comparative Studies in Society and History 44 (4): 638-68.

Campion, B. B. and E. Acheampong (2014) 'The chieftaincy institution in Ghana: causers and arbitrators of conflicts in industrial jatropha investments', Sustainability 6: 6332-50.

Carmody, P. and F. Owusu (2016) 'Neoliberalism, urbanization and change in Africa: the political economy of heterotopias', Journal of African Development 18 (18): 61-73.

Chazan, N. (1983) An Anatomy of Ghanaian Politics: managing political recession 1969-1982. Boulder CO: Westview Press.

Chernoff, J. M. (2003) Hustling Is Not Stealing: stories of an African bar girl. Chicago IL: University of Chicago Press.

Cohen, B. (2006) 'Urbanization in developing countries: current trends, future projections, and key challenges for sustainability', Technology in Society 28 (1): $63-80$.

Davis, M. (2006) Planet of Slums. London: Verso. 
De Boeck, F. and M.-F. Plissart (2004) Kinshasa: tales of the invisible city. Tervuren and Ghent: Ludion and Royal Museum for Central Africa.

De Soto, H. (2000) The Mystery of Capital: why capitalism triumphs in the West and fails everywhere else. New York NY: Basic Books.

De Souza, F. (2001) 'The future of informal settlements: lessons in the legalization of disputed urban land in Recife, Brazil', Geoforum 32: 483-92.

Evans, P. B., D. Rueschemeyer and T. Skocpol (eds) (1985) Bringing the State Back In. Cambridge: Cambridge University Press.

Farouk, B. R. and M. Owusu (2012) "If in doubt, count": the role of communitydriven enumerations in blocking eviction in Old Fadama, Accra', Environment and Urbanization 24 (1): 47-57.

Fourchard, L. (2011) 'Between world history and state formation: new perspectives on African cities', Journal of African History 52: 223-48.

Gillespie, T. (2013) 'Accumulation by urban dispossession: struggles over urban space in Accra, Ghana'. DPhil thesis, University of Leeds.

Gillespie, T. (2016) 'Accumulation by urban dispossession: struggles over urban space in Accra, Ghana', Transactions of the Institute of British Geographers 42: $66-77$.

Government of Ghana (2011) Land Administration Project: phase two. Project implementation main manual. Accra: Ministry of Lands and Natural Resources.

Grant, R. (2006) 'Out of place? Global citizens in local spaces: a study of the informal settlements in the Korle Lagoon environs in Accra, Ghana', Urban Forum 17 (1): 1-24.

Grant, R. (2009) Globalizing City: the urban and economic transformation of Accra, Ghana. New York NY: Syracuse University Press.

Hansen, T. B. and O. Verkaaik (2009) 'Introduction - urban charisma: on everyday mythologies in the city', Critique of Anthropology 29 (1): 5-26.

Harvey, D. (2003) The New Imperialism. Oxford: Oxford University Press.

Herbst, J. (2000) States and Power in Africa. Princeton NJ: Princeton University Press.

Housing the Masses (2010) 'Final report to People's Dialogue on Human Settlements (People's Dialogue, Ghana) on community-led enumeration of Old Fadama community, Accra, Ghana'. N.p.: Housing the Masses <https://knowyourcity.info/wp-content/uploads/2015/04/2009.May3_.2010.Old_Fadama_ Enumeration-1_1.pdf>, accessed 19 October 2017.

Jönsson, J. (2007) 'The overwhelming minority: traditional leadership and ethnic conflict in Ghana's northern region'. CRISE Working Paper 30. Oxford: University of Oxford.

Kaplan, R. (1994) 'The coming anarchy: how scarcity, crime, overpopulation, tribalism, and disease are rapidly destroying the social fabric of our planet', Atlantic Monthly 273: 44-75.

Locatelli, F. and P. Nugent (eds) (2009) African Cities: competing claims on urban spaces. Leiden: Brill.

Lombard, M. (2013) 'Struggling, suffering, hoping, waiting: perceptions of temporality in two informal neighbourhoods in Mexico', Environment and Planning D: Society and Space 31: 813-29.

Lombard, M. and C. Rakodi (2016) 'Urban land conflict in the global South: towards an analytical framework', Urban Studies 53 (13): 2683-99. 
Lund, C. (2006) 'Twilight institutions; public authority and local politics in Africa', Development and Change 37 (4): 685-705.

Lund, C. (2016) 'Rule and rupture: state formation through the production of property and citizenship', Development and Change 47 (6): 1199-228.

Mohanty, M. (2006) 'Urban squatters, informal sector and livelihood strategies of the poor in Fiji Islands', Development Bulletin 70: 65-8.

Myers, G. (2011) African Cities: alternative visions of urban theory and practice. London and New York NY: Zed Books.

Nielsen, M. (2011) 'Inverse governmentality: the paradoxical production of periurban planning in Maputo, Mozambique', Critique of Anthropology 3 (4): 329-58.

Nugent, P. (2010) 'States and social contracts in Africa', New Left Review 63: 35-68.

Obeng-Odoom, F. (2011) 'The informal sector in Ghana under siege', Journal of Developing Societies 27: 355-92.

Paller, J. W. (2015) 'Informal networks and access to power to obtain housing in urban slums in Ghana', Africa Today 62 (1): 31-55.

Peck, J. and A. Tickell (2002) 'Neoliberalizing space', Antipode 34: 380-404.

Potts, D. (2012) 'Challenging the myths of urban dynamics in sub-Saharan Africa: the evidence from Nigeria', World Development 40 (7): 1382-93.

Ribot, J. and N. L. Peluso (2003) 'A theory of access', Rural Sociology 68 (2): 153-81.

Robinson, J. (2006) Ordinary Cities: between modernity and development. Questioning Cities Series. London and New York NY: Routledge.

Rose, C. (1998) 'Canons of property talk, or, Blackstone's anxiety', Yale Law Journal 108 (3): 601-32.

Saglio-Yatzimirsky, M. C. (2013) Dharavi: from mega-slum to urban paradigm. New Delhi: Routledge.

Scott, J. C. (1998) Seeing Like a State. New Haven CT and London: Yale University Press.

Shabane, I., M. Nkambwe and R. Chanda (2011) 'Land use, policy, and squatter settlements: the case of peri-urban areas in Botswana', Applied Geography 31 (2): 677-86.

Shachar, A. and R. Hirschl (2007) 'Citizenship as inherited property', Political Theory 35 (3): 253-87.

Sikor, T. and C. Lund (2009) 'Access and property: a question of power and authority', Development and Change 40 (1): 1-22.

Simone, A. M. and A. Abouhani (eds) (2005) Urban Africa: changing contours of survival in the city. London and New York NY: Zed Books.

Songsore, J., P. Amponsah, O. Alhassan, M. Kala, S. K. Avle and M. A. Chama (2014) Environmental Health and Disaster Risks, Livelihoods and Ecology within the Korle-Lagoon Complex in Accra, Ghana. Accra: Ghana Universities Press.

Spichiger, R. and P. Stacey (2014) 'Ghana's land reform and gender equality'. Working Paper 1. Copenhagen: Danish Institute for International Studies (DIIS).

Stacey, P. (2015) 'Political structure and the limits of recognition and representation in Ghana', Development and Change 46 (1): 25-47.

Stacey, P. and C. Lund (2016) 'In a state of slum: governance in an informal urban settlement in Ghana', Journal of Modern African Studies 54 (4): 591-615.

UN (1997) 'Glossary of environment statistics'. Studies in Methods, Series F, No. 67. New York NY: United Nations. 
UN-Habitat (2011) Participatory Slum Upgrading and Prevention: millennium city of Accra, Ghana. Accra: United Nations Human Settlements Programme (UNHabitat).

Uphoff, N. (1989) 'Distinguishing power, authority and legitimacy: taking Max Weber at his word by using resources-exchange analysis', Polity 22 (2): 295-322. Watson, V. (2009) "“The planned city sweeps the poor away ...": urban planning and 21st century urbanization', Progress in Planning 72: 151-93.

World Bank (2014) Rising through Cities in Ghana: Ghana urbanization review overview report. Washington DC: World Bank Group.

\begin{abstract}
Rural-urban migration leads to ever increasing numbers of Africans living in informal settlements. In Accra's largest informal settlement, Old Fadama, residents by definition have no statutory rights to the land and their building activities undermine formal state law and state-recognized customary landowners. Statutory institutions are unable to enforce property rights and alternative interests emerge and organize. In multiple and fragmented ways, local stakeholders create and define their own informal relations of property and land-based authority. This article examines four cases of land transfers, building and development in the settlement that involve a variety of local, national and global actors. Their actions show the contemporaneous making and unmaking of different relations of property and land-based control and authority in the densely populated urban site. Important features of urban development in Accra are thereby shown to be variations in property relations and the multitude of actors that validate land use but that circumvent statutory institutions.
\end{abstract}

\title{
Résumé
}

En conséquence de l'exode rural, les Africains sont de plus en plus nombreux à vivre dans des peuplements informels. Dans le plus grand peuplement informel d'Accra, Old Fadama, les résidents n'ont, par définition, aucun droit statutaire aux terres et leurs activités de construction sapent le droit étatique formel et les propriétaires fonciers coutumiers reconnus par l'État. Les organes statutaires étant dans l'incapacité de faire appliquer les droits fonciers, des intérêts alternatifs apparaissent et s'organisent. De manières multiples et fragmentées, les parties prenantes locales créent et définissent leurs propres liens de propriété et autorité foncière. Cet article examine quatre cas de transfert, de construction et d'aménagement fonciers dans le peuplement impliquant divers acteurs locaux, nationaux et globaux. Leurs actions montrent la construction et la déconstruction contemporaine de différents liens de propriété et d'autorité foncière dans ce site urbain densément peuplé. L'auteur montre que les importantes caractéristiques de l'urbanisme à Accra sont des variations des liens de propriété et la multitude d'acteurs qui valident l'utilisation des terres, mais que contournent les organes statutaires. 